\title{
K CENTRÁLNÍMU PARADOXU ADORNOVY „MINIMÁLNÍ THEOLOGIE“ Adornovo dílo jako kontemplativní eschatologie
}

\author{
Karel Hlaváček
}

\section{Úvod}

V jednom ze svých novějších textů upozorňuje Jürgen Habermas na to, že Adorno je „obtížný" “1 v tom smyslu, že jeho filosofie a sociální teorie jsou vzdálené současným diskusím. Habermas přitom nehovoří pouze sám za sebe - hovoří o „váhavosti specialistů“2 obecně. Habermasovo vyjádření se snaží zachytit obecnější postoj současných akademiků vůči Adornovi.

Domnívám se, že tento váhavý přistup k Adornovu dílu je oprávněný jen tehdy, prohlásíme-li za pravdivé určité předpoklady. Základním předpokladem tohoto typu je, že filosofie a sociální teorie musí zůstat striktně sekulární. Tento článek takový předpoklad odmítá a hledá v Adornovi náboženské motivy, jež by mohly být inspirativní pro filosofii a sociální teorii, která se neuzavírá vůči náboženským motivům. Vychází z toho, že jestliže se určitý náboženský motiv jeví jako rozumově oprávněný, nemůže být jednoduše zamítnut jen z toho důvodu, že není striktně sekulární.

Má teze v tomto článku je následující: Přezkoumáme-li Adornovu filosofii a sociální teorii ve světle jejích náboženských prvků, vyvstává před námi paradoxní, ale životný a inspirativní obraz, z něhož může nadále čerpat radikální kritika současné společnosti. $Z$ tohoto hlediska označuji Adornovu filosofii v návaznosti na Henta de Vriese jako „minimální theologii“ a předestírám její podobu jako „kontemplativní eschatologii“, tj. jako nauku o posledních věcech s judeokřest'anským pozadím, jejímž hlavním obsahovým prvkem je realizovaná „kontemplace“.

Adorno na jednu stranu žádá správnou praxi (revoluci), na druhou stranu ale z jeho díla vyplývá, že jakákoli správná praxe je nemožná,

1 J. Habermas, Zwischen Naturalismus und Religion. Philosophische Aufsätze, Frankfurt a. M. 2005, str. 187.

2 Tamt. 
protože by se zvrhla v instrumentální násilí. Tvrdím, že tento paradox je při recepci Adornova díla obzvláště obtížným momentem a vede Adornovy kritiky - at' už je to Habermas, Žižek, Seel či další - k tomu, že jeho dílo odmítají a volí jiné cesty ke kritice společnosti. Domnívají $\mathrm{se}$, že Adornova cesta je zachycena $\mathrm{v}$ neřešitelném paradoxu, kterého je nutno se zbavit, a to bud' odmítnutím myšlenky revoluce, nebo jejím jednoznačným prijietím. Je tomu ale vskutku tak, jak tvrdí tito kritikové? Je paradox neuskutečnitelné utopie skutečně slabým bodem Adornovy filosofie, nebo naopak jedním z jejích nejsilnějších momentů?

V rozporu mezi požadavky „kontemplace“ a „eschatologie“ nacházím centrální paradox Adornova díla, který se promítá do dalších napětí v jeho díle - např. do napětí mezi nemožností revoluce a touhou po revoluci, mezi teorií a praxí, mezi respektem před „,neidentickým“ a snahou rozlomit totalitu identity, mezi nenásilím a jednáním, mezi obavou před instrumentálním rozumem a touhou po změně. Přitom tvrdím - na rozdíl od mainstreamového čtení Adornova díla-, že tento paradox není něčím, co bychom měli odmítnout. Naopak, jedná se o motiv, kterým Adorno hluboce zachytil reálný rozpor, $\mathrm{v}$ němž se - biblicky řečeno - nachází „tento svět".

Abych rozvinul výše nastíněnou tezi, postupuji následujícím způsobem: nejprve shrnuji diskusi o Adornově díle z hlediska jeho náboženského prvku, poté nastiňuji vlastní pojetí adornovské „minimální theologie“" a nakonec se věnuji rozboru paradoxu, v němž je tato „theologie“ údajně uvězněna.

Celým článkem přitom prolíná diskuse o možnosti a oprávněnosti označovat Adornovo dílo jako „theologii“. Hovořím-li o „náboženském“ prvku v Adornově díle či o jeho „theologii““, je třeba tyto pojmy vždy vnímat s určitou rezervou. Měla-li by být brána jako tvrzení, že Adorno byl přívržencem tradičních náboženství - judaismu či křest’anství -, jednalo by se zajisté o tvrzení chybné. Adorno byl materialistou a racionalistickým kritikem tradičních náboženství; chtěl je sekularizovat. Návaznost na tradiční náboženství je u něho nicméně natolik silná, že se v akademické sféře prosadila možnost označení jeho díla jako formy „theologie“, a to i tehdy, předpokládá-li se, že Adorno theologii vskutku sekularizoval. V tomto článku ale pojem „theologie“ či „náboženství“ nakonec nabírá doslovnějšího významu, protože přicházím s tvrzením, že Adornova sekularizace náboženských motivů je neúplná, a právě v tom spočívá silná stránka jeho „theologie“.

Teze tohoto článku předpokládá, že Adorna je svým způsobem nutno číst proti jeho vlastní intenci, protože tento autor nezamýšlel provést 
pouze částečnou, nýbrž úplnou sekularizaci theologie. Nedomnívám se ovšem, že by se jednalo o nějaké znásilnění jeho díla. Sám Adorno totiž tvrdí, že „rozumění ... není nic takového jako vyloupnutí toho, co autor údajně chtěl říci ... Pohnutky autora se ztrácejí v objektivním obsahu, který uchopují “. 3 Soustředím se tedy nikoli na Adornovu intenci, ale na to, co nacházím $\mathrm{v}$ jeho textech. A zde nacházím paradox, který překračuje jeho předpokládanou intenci a vyžaduje interpretaci, která vyjde za ni. Jedná se o dekonstruktivní četbu Adorna v tom smyslu, že to, co se $\mathrm{v}$ jeho textech nachází sice na okraji, ale nachází se v nich - totiž náboženský prvek -, se přesouvá do centra pozornosti.

\section{Adornovo dílo jako „theologie“?}

Adornovo dílo je často označováno jako forma „theologie“.4 To je samo o sobě možno vnímat jako poněkud paradoxní, protože Adorno se proti tradičně pojatému náboženství poměrně ostře vymezoval. Ve svém eseji Rozum a zjevení prohlašuje přijetí náboženství za „obětování intelektu“5 a vykresluje obraz, ve kterém se náboženství v sekulární západní společnosti jeví jako iracionální. Adorno se domnívá, že náboženská víra je skokem do heteronomie - nejdříve musím uznat autoritu a pak věŕím ${ }^{6}$ a v moderním sekulárním světě vyrůstá $\mathrm{z}$,potřeby orientace, ulpění na pevně daném“, z marné naděje, že můžeme „rozhodnutím vdechnout odkouzlenému světu onen smysl, jehož nedostatkem tolik trpíme, když jako pouzí diváci civíme na bezesmyslnéc. ${ }^{7}$

3 T. W. Adorno, Philosophie und Gesellschaft, Stuttgart 1984, str. 6-7 (český překlad je můj vlastní).

4 Autorů a publikací, které zmiňují Adornovo dílo jako „theologii“, je v zásadě nepřehledné množství. Patří mezi ně např. S. Buck-Morss, The Origins of Negative Dialectics, New York 1977; Ch. C. Brittain, Adorno and Theology, London - New York 2010; H. de Vries, Minimal Theologies, Critiques of Secular Reason in Adorno and Lévinas, Baltimore - London 2005. Existují nicméně i autoři, kteří Adornovu př́slušnost $\mathrm{k}$ theologii zpochybňují a tvrdí, že ho nelze řadit k náboženskému obratu ve filosofii nebo postsekulárnímu myšlení. Mezi ně patří např. M. Waggoner, Giving up the Good. Adorno, Kierkegaard, and the Critique of Political Culture, in: Journal for Cultural and Religious Theory, 6, 2005, str. 63-83. V tomto článku prezentuji tezi, podle které je Adornovo zařazení do „theologie oprávněné“.

5 T. W. Adorno, Stichworte, Kritische Modelle, II, Frankfurt a. M. 1969, str. 22 (český překlad je můj vlastní).

6 Tamt., str. 25.

7 Tamt., str. 22. 
Bez ohledu na to, nakolik je taková kritika dnes ještě možná a oprávněná, ${ }^{8}$ není Adornův př́stup k náboženství ve skutečnosti zdaleka jednoduchý nebo jednostranný, jak jeho kritika naznačuje. Adorno je silně ovlivněn náboženskými motivy, které mohou být dokonce interpretovány jako centrální body jeho filosofie a sociální teorie. Sám koneckonců ve svých dopisech Benjaminovi označuje své snahy pojmem ,inverzní theologie“ či „,negativní theologie“9 a hovoří o tom, že jeho „práce chce bez okolků směřovat k realizaci theologického obsahu ve vší doslovnosti jeho nejextrémnějších požadavků“'. ${ }^{10}$

To, o co Adornovi jde, není nic menšího než - jak sám říká - „vykoupení“ (Erlösung). Např. v často citovaném posledním aforismu díla Minima Moralia Adorno píše se sobě vlastní nekompromisní radikalitou, že není myslitelná jiná filosofie než ta, která operuje právě se směřováním k vykoupení: „Filosofie, kterou lze tváří v tvář zoufalství jedině ospravedlnit, by byl pokus pojímat všechny věci tak, jak by se ukazovaly z hlediska vykoupení. Poznání nemá žádné jiné světlo než to, které dopadá na svět z vykoupení: vše ostatní se vyčerpává v dodatečné konstrukci a zůstává kusem techniky."11

Na jiných místech vyjadřuje Adorno toto kvazináboženské směřování svého díla odlišnými pojmy, které rovněž čerpají z theologické tradice a specifikují jeho záměry: Např. klade důraz na tělesné zabarvení ideálu „vykoupení“. Svůj materialismus tak popisuje následujícím způsobem: „Jeho touhou by bylo zmrtvýchvstání těla ... Útočištěm historického materialismu by bylo jeho zrušení, osvobození ducha od primátu materiálních potřeb ve stavu jejich naplnění."12 Další zásadní moment je moment nenásilí - vykoupení je u Adorna současně momentem, v němž je zrušeno násilí. Říká: „Usmíření (Versöhnung) by byla pamětlivost

8 Tuto kritiku zamítá Adornův nástupce Habermas, když se staví za potenciální racionalitu náboženství (viz J. Habermas, Zwischen Naturalismus und Religion, str. 12-13). Kromě Habermase lze dnes za základní text k možnosti kritiky náboženství považovat knihu Ch. Taylora, Sekulární věk. Dilemata moderní společnosti, přel. T. Chudý - O. Štěch, Praha 2013 - a rovněž v tomto kontextu se Adornova kritika jeví jako nepřiměřená.

9 S. Buck-Morss, The Origins of Negative Dialectics, str. 195.

10 T. W. Adorno - W. Benjamin, The Complete Correspondence: 1928 1940, vyd. H. Lonitz, přel. N. Walker, Cambridge 1999, str. 53. Citováno podle: Ch. C. Brittain, Adorno and Theology, London - New York 2010, str. 2.

11 T. W. Adorno, Minima Moralia, přel. M. Ritter, Praha 2009, str. 244.

12 T. W. Adorno, Negative Dialektik, Frankfurt a. M. 1966, str. 205 (český překlad je můj vlastní). 
rozmanitosti, která již není nepřátelská ... Dialektika stojí ve službách usmíření."13

Náboženský přídech Adornových spisů je podtržen faktem, že ideu „vykoupení“ podmiňoval zákazem zobrazování Božského (Bilderverbot), který je známý především z judaismu. Adorno k tomu říká: „Vědomí, které by mezi sebe a to, co myslí, podsouvalo obrazy, by nepozorovaně reprodukovalo idealismus; korpus představ by substituoval předmět poznání, a subjektivní zvůle takových představ je zvůlí nařizujícího. Materialistická touha pochopit věc chce opak: celý objekt je možno myslet pouze bez obrazů. Taková bezobraznost konverguje s theologickým zákazem zobrazování. Materialismus ji sekularizoval, čímž nedovolil, aby utopie byla pozitivně vykreslena."14

Ve světle tohoto směřování Adornova díla se tedy vede diskuse nad jeho filosofií jako formou theologie. Kromě již zmíněných pojmů ,inverzní“ či „negativní“ theologie byla popisována také jako „sekulární theologie“15 či „minimální theologie“. ${ }^{16}$ Diskuse o těchto označeních dosud nenalezla jasný výsledek; jeden ze zásadních sporných bodů zde přitom představuje otázka, zda Adornova negativní dialektika předpokládá či nepředpokládá pozitivní theologický a současně rozumu transcendentní obsah.

Christopher C. Brittain, jehož monografii ke vztahu Adorna a theologie lze považovat za vyústění dosavadních debat, shrnuje vztah Adorna a theologie tvrzením, podle něhož „se theologie nachází těsně pod

13 Tamt., str. 16.

14 Tamt., str. 204-205.

15 Kaufmann, který v souvislosti s Adornem hovoří o „sekulární theologii“, ospravedlňuje tento pojem židovskou tradicí, která se v protikladu k theologii křest’anské nesoustředí tolik na spekulaci o Bohu, ale spíše na člověka a jeho vztah ke světu, což Adorno činí rovněž. Adorno je „theologický“, i když neuznává zjevení, protože se snaží (v protikladu k Heideggerově fundamentální ontologii) postavit vykupitelskou ontologii. D. Kaufmann, Beyond Use, within Reason: Adorno, Benjamin and the Question of Theology, in: New German Critique, 83, 2001, str. 154.

16 Mluvíme-li o theologickém či náboženském prvku u Adorna, je třeba zmínit také estetickou (zejména hudební) stránku tohoto Adornova směřování. Např. Steinberg hovoří o „hudebním absolutnu“ u Adorna a tvrdí, že „hudba se stává pro kritickou teorii paradigmatem“. M. P. Steinberg, Adorno. The Musical Absolute, in: New German Critique, 56, 1992, str. 41. Obsahy, které v tomto článku analyzuji jako „náboženské“, koření (kromě lidského utrpení symbolizovaného Osvětimí) výrazně také v Adornově estetické zkušenosti. Tento motiv by zasluhoval další pozornost. 
povrchem všech Adornových spisů a proniká každým slovem“; 17 když označuje Adornovo dílo, hovoří po jeho vzoru o ,inverzní theologii““.18 V praxi má označení „theologie“ oprávnění v tom, že Adorno se nechce náboženských obsahů zbavit, nýbrž je chce sekularizovat. Adorno říká, že „nic z theologického obsahu nebude moci přetrvat bez proměny; každý jeden se bude muset vystavit tomu, že bude začleněn do profánního“. ${ }^{19}$ Současně Adorno nechce předpokládat pozitivní theologii. Jak ve své skvělé studii k Adornovi poznamenává Hans Ernst Schiller, „z theologie nezbývá více než zdráhání vyplnit prázdné místo, které zbylo po smrti Boha, idoly bezbožné (heillos) profánnosti““. ${ }^{20}$ Hovoří-li tedy Adorno o „inverzní theologii“, spočívá ona „inverze“ jednak ve stažení do tohoto světa, v sekularizaci, jednak v tom, že Adornova theologie nechce předpokládat pozitivní theologické obsahy. ${ }^{21}$ Adornova práce tedy chce být sekularizovanou theologií, která nestaví na pozitivních náboženských představách.

Brittain, jak již bylo řečeno, podporuje název „inverzní theologie“. Obhajuje jednak tezi o sekulárním charakteru Adornovy „theologie“, jednak tezi o její „,negativitě“. Její sekulárnost spočívá v tom, že se týká „tohoto světa“ (nikoli nějakého zásvětí), její negativita v tom, že slouží k otevření světa pro možnost změny (nikoli ale skrze příslib nějaké náboženské transcendence nebo jiných pozitivních obsahů). Brittain rríká: „Theologický element v Adornově práci je využit, aby rozlomením uvolnil existující život; aby vytvořil prostor pro nové náhledy."22 Podle

17 Ch. C. Brittain, Adorno and Theology, str. 7.

18 Tamt., str. 101.

19 T. W. Adorno, Stichworte, Kritische Modelle, str. 22.

20 T. W. Adorno, Negative Dialektik, str. 362. Citováno podle: H. E. Schiller, Zergehende Transzendenz. Theologie und Gesellschaftskritik bei Adorno, in: M. Lutz-Bachmann (vyd.), Kritische Theorie und Religion, Frankfurt a. M. 1997, str. 84. Schillerovu studii pokládám za vynikající - na relativně malém prostoru analyzuje Adornův vztah k náboženství do takové hloubky, které ostatní studie nedosahují ani při rozsahu podstatně větším. Současně je tato studie pozapomenutá, protože se vyskytuje pouze v německojazyčném sborníku. Nedostatek této studie spočívá snad pouze v tom, že - stejně jako všechny studie k tomuto tématu, s nimiž jsem se setkal - nereflektuje dostatečně masivní pozitivní obsahy Adornovy „,inverzní theologie“" (viz dále v textu).

21 O ,inverzní theologii“ u Adorna hovoří např. Pritchard. Ta zdůrazňuje, že Adornova inverzní theologie chce „,negovat negaci“, tj. negovat poškozený život. E. A. Pritchard, Bilderverbot Meets Body in Theodor W. Adorno's Inverse Theology, in: The Harvard Theological Review, 95, 1992, str. 295.

22 Ch. C. Brittain, Adorno and Theology, str. 8. 
Brittaina klade Adorno důraz na „negativní kritiku existujícího života, motivovaný zájmem o utopické potenciality“, aniž by ovšem předpokládal „pozitivní, ale absentující realitu“. ${ }^{23}$ Pojem „negativní theologie“, který používá např. Susan Buck-Morssová, ${ }^{24}$ Brittain kritizuje, protože vzbuzuje dojem, že Adorno přináleží klasické theologické tradici a že jeho dílo předpokládá pozitivní transcendentní obsah. To by ovšem znamenalo, že Adorno předpokládá něco mimo rozum, což podle Brittaina není pravda. ${ }^{25}$

S odlišnou interpretací přichází např. Hent de Vries, podle něhož Adorno staví „minimální theologii“, v níž se ohlašuje „stopa jiného“, tj. právě určitý pozitivní nerozumový obsah (jakkoli je tento obsah „minimální"). Podle de Vriese nelze tvrdit, že by Adornova filosofie byla čistě „negativni““, nýbrž - stejně jako negativní pojetí dialektiky osvícenství - je závislá na oné „stopě jiného“, tj. na pozitivním obsahu. ${ }^{26} \mathrm{De}$ Vries tvrdí, že Adornovy pojmové modely indikují „limity fenomenality, stopu jiného, absolutního, nekonečného, ale také neidentického““. ${ }^{27} \mathrm{Vy}-$ užití „stopy jiného“ je podle de Vriese smyslem Adornova pokusu být solidární s metafyzikou v momentě jejího pádu.

Střední cestu mezi oběma výše uvedenými interpretacemi tvoří výše zmíněný Schiller. Ten se domnívá, že právě Adornovo zdráhání vyplnit prázdné místo po Bohu profánními obsahy je tím, co ,udržuje theologii naživu“. ${ }^{28}$ Podle Schillera zůstává Adorno aporetický, stojí mimo theologii a náboženství, ty ale v jeho díle paradoxně nadále žijí. Schiller se domnívá, že u Adorna „není jiné transcendence než transcendence touhy“; 29 náboženská transcendence v jeho díle současně je i není. Podobné směřování svých úvah o Adornovi naznačuje i Habermas, když komentuje theologické předpoklady Adornova díla: „,[Adorno] ví, že neexistuje žádný Bůh, a přece v něj věří. “30

23 Tamt., str. 95.

24 S. Buck-Morss, The Origins of Negative Dialectics, New York 1977, str. 90.

25 Ch. C. Brittain, Adorno and Theology, str. 93.

26 H. de Vries, Minimal Theologies, str. 168.

27 Tamt., str. 32.

28 H. E. Schiller, Zergehende Transzendenz, str. 84-85.

29 Tamt., str. 85.

30 J. Habermas, Budoucnost lidské přirozenosti, přel. A. Bakešová, Praha 2003, str. 123. 


\section{Prvky Adornovy „minimální theologie“: kontemplativní eschatologie}

Výše zmíněné interpretace Adornovy „theologie“ nakonec kulminují v otázce, zda Adorno předpokládá či nepředpokládá pozitivní theologický a současně vůči rozumu transcendentní obsah. V tomto sporu mám tendenci postavit se spíše na stranu Henta de Vriese a těch autorů, kteří hovoří o prrítomnosti určitého pozitivního a rozum transcendujícího předpokladu. Nakonec i Adornovo již citované tvrzení, že ,poznání nemá žádné jiné světlo než to, které dopadá na svět z vykoupení“, 31 hovoří poměrně jednoznačně o tom, že Adorno staví na něčem pozitivním, co popisuje jako „světlo vykoupení“; zdráhá se nicméně tento nejasný základ jasně pojmově specifikovat. Pochybnost o tom, zda takový nespecifikovatelný obsah je integrální rozumu, je, domnívám se, na místě. ${ }^{32}$ Podle mého názoru je třeba radikálně pochybovat o všech ,ryze negativních“ a jiných „ryzích“ př́stupech. Neexistuje zřejmě žádná čistá negativita; i u Adorna čerpá poznání světlo z „vykoupeni““, tj. z něčeho pozitivního, nikoli, jak se domnívá Houseman, pouze z negativního eschaton Osvětimi. Kdyby toto vykoupení bylo jakýmsi „nic“, kde by se toto světlo vzalo?

Stopu jiného, kterou v Adornovi nacházíme a o níž hovoří de Vries, lze objevit např̀. v následujícím Adornově výroku: „Kdyby byla smrt oním absolutnem, které by filosofie marně zaklínala, pak je vše ničím, i každá myšlenka míŕí do prázdna, žádnou není možno myslet pravdivě." ${ }^{33}$ Adorno se tedy obává, že absolutnost smrti, tj. její konečné vítězství, by znamenalo, že jeho filosofie, která protestuje proti smrti symbolizované Osvětimí, by nakonec byla celá nesmyslná, protože by se

31 T. W. Adorno. Minima Moralia, str. 244.

32 Tento motiv blíže rozpracovávám dále v textu. Má interpretace ovšem vychází za předpokládanou Adornovu intenci, jak již bylo uvedeno v úvodu. Adorno zřejmě nechtěl předpokládat pozitivní theologické obsahy; vzhledem k této intenci pokládám za nejpřiléhavější Schillerovu interpretaci, podle které je Adorno aporetický. Brittainovo naléhání na to, že Adorno své dílo vskutku plně sekularizoval a současně ho udržel negativní, pokládám za jednostranné. Důvody k tomu rozebírám dále v textu. Jestliže je ovšem Adorno aporetický, jak to tvrdí Schiller, a jestliže se aporie jeví neudržitelnou, neznamená to, že bychom se sami měli přiklonit k jedné z interpretací, kterou považujeme za správnější? Proto nezůstávám u Schillerova konstatování, ale přesouvám se směrem k interpretaci de Vriesova typu, jakkoli taková interpretace jistě překračuje to, co Adorno vědomě zamýšlel.

33 T. W. Adorno, Negative Dialektik, str. 362. Citováno podle: H. E. Schiller, Zergehende Transzendenz, str. 72. 
koneckonců jednalo jen o menší časový odklad smrti. Materialismus, který Adorno podle vlastní dikce zastává, ovšem žádnou „porážku smrti“ a trvalé vítězství života nenabízí; jako ryze imanentní filosofie by musel zůstat u konstatování faktu smrti. Zde se rýsuje „stopa jiného“ či „theologická výhrada“ Adornova díla: aby samo sebe mohlo považovat za smysluplné, odmítá přijmout s konečnou platností absolutnost smrti. A to i přesto, že Adorno současně říká, že ,poznání se přiklání hluboko na stranu absolutní smrtelnosti...".34

Nejpřiměřenější interpretací Adornova díla samého je v tomto místě zřejmě interpretace Schillerova, která jednoduše konstatuje, že v Adornově díle nacházíme nerozřešenou aporii. Adorno se, jak sám přiznává, ocitá v místě, před kterým zůstává jeho „rozum stát“. Říká: „Její idea [smrtelnosti] se myšlení vysmívá neméně než idea nesmrtelnosti."35 Přesto je ale platná i de Vriesova teze, že totiž Adorno tím, že myšlenku smrtelnosti odmítá, využívá „stopu jiného“, využívá stopy pozitivního theologického obsahu, který je současně vůči rozumu, jak mu rozuměl Adorno, vnější.

Na obdobný moment u Adorna poukazuje také papež Benedikt XVI. ve své encyklice Spe Salvi, v níž Adorna označuje za „velkého filosofa“ (a upozorňuje, že Adorno nekritizoval jen theismus, nýbrž i atheismus), a i když kritizuje Adornův prŕíklon k absolutnímu zákazu zobrazování, oceňuje, že Adorno požaduje svět, , $\mathrm{V}$ němž by bylo zrušeno nejen současné utrpení, ale odvoláno také utrpení neodvolatelně minulé“، ${ }^{36} \mathrm{Na}$ tomto místě opět zůstává aporie: Adorno požaduje „odvolání neodvolatelného", tj. doslova něco nemožného - transcendence se jeví jako nemožná. Současně ale Adorno na stejném místě tvrdí, že „myšlenka, která sama sobě nechce utnout hlavu (sich enthaupten), ústí do transcendence [světa, v němž je odvoláno neodvolatelné]“،.37 Požaduje-li Adorno takovýto spravedlivý svět, nemusí u toho snad předpokládat cosi, co by takovou spravedlnost zajišt’ovalo, tj. určitý theologický základ? Tento theologický základ není plně prítomen, zůstává ale jako „stopa“.

34 T. W. Adorno, Negative Dialektik, str. 391-392.

35 Tamt., str. 362. Citováno podle: H. E. Schiller, Zergehende Transzendenz, str. 72.

36 T. W. Adorno, Negative Dialektik, str. 393. Citováno podle: Benedikt XVI., Spe Salvi, dostupné online: http://w2.vatican.va/content/benedict-xvi/de/encyclicals /documents/hf_ben-xvi_enc_20071130_spe-salvi.html [19. 4. 2016] (český překlad je můj vlastní).

37 T. W. Adorno, Negative Dialektik, str. 393. 
Zdá se tedy, že celá Adornova filosofie stojí na určitém minimálním theologickém a vůči rozumu vnějším předpokladu, na něčem, co může zajistit, že smrt není absolutní a že existuje spravedlnost, která zruší pozemskou nespravedlnost. Jakkoli je takový základ nejasný a diskutabilní, zdá se, že Adornův materialismus skutečně ústí ve zrušení sebe sama, a to v radikálnějším smyslu, než je osvobození od nadvlády matérie nad duchem v marxovském smyslu. Celý Adornův materialismus, zdá se, stojí a padá s předpokladem, který se do jeho rámce nevejde, s minimalizovaným theologickým předpokladem, podle něhož smrt nesmí být absolutnem a musí existovat nadpozemská spravedlnost. Adornův materialismus je tak vskutku interpretovatelný jako „minimální theologie“.

\section{Pozitivní centrum negativní dialektiky}

Celkově ale tvrdím, že debata musí sestoupit o úroveň níže: netažme se jen po tom, zda Adorno předpokládá pozitivní theologický a z jeho hlediska nerozumový obsah. Tažme se v první řadě po tom, zda Adorno navzdory „negativnímu“ charakteru své dialektiky využívá pozitivní obsahy obecně. Teprve poté budeme schopni adekvátně odpovědět i na výše uvedenou otázku po pozitivním theologickém obsahu Adornova díla. Argumentace, podle které se Adorno snaží být (a rovněž může být) ryze negativní a nepředpokládat pozitivní obsahy, resp. pouze jejich nejasné stopy - jak problém staví Brittain, de Vries, Houseman a další -, zůstává totiž v zajetí Adornovy sebeprezentace, která hovořila o „,negativní dialektice“, tj. stavěla sama sebe jako negaci (kritiku) negace (poškozeného života). Čistá negativita by ale znamenala absenci pozitivního obsahu, tedy vposled i předpokladů, ze kterých vychází. Takové předpoklady jsou ale zřejmě podmínkou možnosti jakéhokoli poznání. Určité pozitivní předpoklady tedy v Adornově „theologii“ být musí - to, jestli jsou rozumové nebo rozum transcendující, je jiná otázka.

Ve světle takto vykresleného problému se ukazuje, že jak Brittainův či Housemanův předpoklad negativity, tak i de Vriesův koncept „stopy“ transcendence zůstávají hluboce zanořeny v Adornově zavádějícím tvrzení o vlastní negativitě. Toto tvrzení je zavádějící, protože, jak se ukazuje, Adornova negativita předpokládá vskutku masivní pozitivní obsah.

S rozkrytím tohoto obsahu Adornovy negativní dialektiky přišel frankfurtský teoretik Martin Seel. Ten zcela odmítl tezi, že by Adornova dialektika byla skutečně „negativní“ a chce ukázat „pozitivní centrum 
jeho negativního myšlení“. 38 Ř́ká, že „,by bylo na čase osvobodit Adornovu filosofii od dogmatu a traumatu její negativity“. ${ }^{39}$ Adornův názor, že dobro může být vyobrazeno pouze negativně, Seel vidí jako jeho sebeklam: „,[Adorno] vychází radikálně z pozitivních zkušeností, a navíc z radikálně pozitivních zkušeností.“"40

Tyto zkušenosti přitom podle Seela nejsou záležitostí nepř́itomné utopie, nýbrž se nacházejí „uprostřed spravovaného světa (verwaltete Welt)“. ${ }^{41}$ Pozitivní obsah Adornovy filosofie pak Seel nenalézá v enigmatických minimalizovaných konceptech, jako je „stopa jiného“, nýbrž $\mathrm{v}$ daleko masivnějším a jednoznačnějším principu, který Adorno odvodil ze zkušenosti neinstrumentálních vztahů a estetické zkušenosti a který by bylo možno nazvat „kontemplací“. Seel tvrdí: „Toto normativní jádro [Adornovy filosofie] leží v originální a svébytné teorii kontemplativní pozornosti, v níž se nerozlučitelně propojují motivy teoretické filosofie, etiky a estetiky." ${ }^{2}$

Kontemplace, jak říká Seel, ,je latinským překladem řecké theória. Adorno přichází s teorií teorie. Je to ale současně teorie praxe. Kritériem pro správnou praxi je její otevřenost pro onen pohled kontemplace, o němž se v Minima Moralia píše, že teprve v něm se vyjasňují věci a lidé" 43

Podle Seela je „kontemplace“ jádrem Adornovy filosofie ve vskutku základním smyslu: Tvoří jeho teorii poznání, jeho etiku a koření v jeho estetice. Adornova teorie poznání je podle Seela „kontrolovaným subjektivismem“, 44 Adorno se pokouší, „,vycházeje z vlastní zkušenosti, nehovořit pouze o své zkušenosti“ 45 a měř́tko „objektivity a všeobecnosti, kterou Adorno tak energicky pro své poznání nárokuje..., nespočívá ve verifikaci hájených tezí opakovaným přezkušováním, nýbrž v individuální lidské zkušenosti, udržované nadějí a desiluzi“ “. ${ }^{46} \mathrm{~V}$ kon-

38 M. Seel, Adornos Philosophie der Kontemplation, Frankfurt a. M. 2004, str. 2 (český překlad je můj vlastní).

39 Tamt., str. 29.

40 Tamt., str. 34-35.

41 Tamt., str. 35.

42 Tamt., str. 2.

43 Tamt., str. 7.

44 Tamt., str. 31.

45 Tamt., str. 30.

46 Tamt., str. 31. 
templativní pozornosti věnované objektu tak u Adorna vzniká zkušenost, která je základem „objektivního“ lidského poznání.

Kontemplace ale není pouze formou teorie poznání, nýbrž i specifickou etikou. To, aby byl lidské zkušenosti přiznán status objektivity, je u Adorna podmíněno etickým předpokladem nenásilí vůči objektu, tak jak se vyjevuje právě $\mathrm{v}$ „kontemplaci“. Jde o nenásilnou pozornost, v níž poznání už není pouhým ,przněním“ obdobným znásilňování žen v dobytém městě: „V dlouhém, kontemplativním pohledu, v němž se lidé a věci teprve vyjasňují, je zároveň reflektována již zlomená touha po objektu. “" ${ }^{77}$ Stejný motiv, který tvoří Adornovu teorii poznání, je tak současně nosným etickým elementem jeho filosofie: „Ve vztazích k jiným a jinému, které jsou osvobozeny od účelu, vidí Adorno jádro zkušenosti, jež motivuje a nese jeho kritiku stavu společnosti." Adornovy filosofie tak pro Seela nakonec leží v osvobození od účelu, tj. v proražení instrumentálního jednání, které se děje právě v kontemplaci.

Seelův postřeh nelze nadále ignorovat. Jeho diagnózu jádra Adornovy filosofie ve výše nastíněné podobě považuji za správnou. Rozbory náboženského prvku u Adorna dosud zásadním způsobem přeceňovaly Adornovu negativní orientaci a nedoceňovaly jeho ideál kontemplativní pozornosti. Adorno nezastává pouze negativní mesianismus, je to rovněž pozitivní „filosof kontemplace“.

Seel však při popisu Adornova díla nehovoří o „theologii“, nýbrž o „filosofii“ a její jádro klade do sekulárně pojaté etiky. Ve svých vývodech nezohledňuje diskusi o Adornovi a jeho vztahu k náboženství; pro něho se tak jedná o ryze sekulární filosofii. Domnívám se nicméně, že je to právě Adornova etika, jíž nelze adekvátně porozumět pomocí sekulárních pojmů. ${ }^{49}$ Právě proto ostatně Adorno sám využívá pojmů náboženských, jako je „,vykoupení“ či „zmrtvýchvstání těla“ atp.

47 T. W. Adorno, Minima Moralia, str. 89. V daném úryvku Adorno kritizuje Fichtův pojem „Tathandlung“; Adorno v něm nekontemplativní jednání přirovnává ke znásilnění ženy mužem (vzhledem k významu tohoto úryvku jej cituji ještě ve vlastním překladu): „Čisté jednání (reine Tathandlung) je prznění projikované na hvězdné nebe nad námi. Avšak dlouhý, kontemplativní pohled, v němž se lidé a věci teprve vyjasňují, je vždy tím pohledem, v němž je chtíč po objektu (Drang zum Objekt) zlomen, reflektován.“ T. W. Adorno, Minima Moralia. Reflexionen aus dem beschädigten Leben, Frankfurt a. M. 1951, str. 156-157.

48 M. Seel, Adornos Philosophie der Kontemplation, str. 34.

49 Stejně jako u Adornova utopického mesianismu je i u jeho „kontemplace“ vysledovatelný pozitivní vztah k tradičnímu náboženství; v případě „kontemplace“ konkrétně k židovské mystice. Adorno např. výslovně přiznává překryvy své filosofie s židovskou mystikou, reprezentovanou historikem kabaly Gershomem 
Domnívat se, že jsme vystihli celek Adornovy filosofie právě principem kontemplace, jak to nakonec činí Seel, se zdá být silně reduktivní. Adornova filosofie vskutku je „filosofií kontemplace“, ale je pouze filosofií kontemplace? Proti Seelovi lze velice dobře argumentovat např. pomocí odlišné interpretace Adornova díla, která by jeho dílo označila za „filosofii neidentického“. Jestliže Adorno trvá na tom, že pojmy jsou nedostatečné a mají své „,neidentické“, neprotiví se pak snaha jeho dílo pojmově vyčerpat jediným principem „kontemplace“ smyslu jeho filosofie?

Podle mého názoru je třeba pochopit Seelův postřeh jako důležitý prvek do mozaiky, v níž se Adornovo dílo vyjevuje opět o něco jasněji než dřive. Tento prvek ale nelze absolutizovat - takový krok by představoval snahu Adornovo dílo předčasně „odkouzlit““ či „ochočit“, tak abychom už nemuseli dávat pozor na „neidentické“ a na Bilderverbot. Kontemplaci je podle mého názoru třeba pochopit jako základní pozitivní obsah toho, co Adorno nazýval „vykoupením“. Realizovaná kontemplace je základním pozitivním obsahem jeho utopie.

Seelův postřeh je tak důležitý v tom, že diskuse, které stále předpokládaly čistou či téměr čistou negativitu Adornovy filosofie, jsou usvědčeny z nedůslednosti. Je ovšem reduktivní v tom, že nezohledňuje vztah Adorna k náboženství a že jeho filosofii redukuje na princip „kontemplace“. Adorno není filosofem kontemplace, nýbrž filosofem „kontemplativní utopie“, nebo, jak se pokusím ukázat dále, „kontemplativní eschatologie“. Theologický obsah Adornova díla se skládá ze dvou obdobně důležitých principů: První z nich je utopický či eschatologický budoucnostní prvek „vykoupení“, druhý z nich je přítomnostní prvek „kontemplace“. Adornovo „vykoupení“ spočívá ve schopnosti realizovat „kontemplaci“, tj. nenásilný a pozorný vztah k objektu, který do něho nebude promítat sebe sama a vlastní touhu po přežití, nýbrž nechá promluvit jeho vlastní intenci.

Scholemem: „Stažení z mystiky do profánního, o kterém jsem před desetiletími z neznalosti věřil, že ho musím uplatnit proti Scholemovi, se ve svém zájmovém směřování podivuhodně překrývá s antinomickými koncepcemi kabaly.“ (T. W. Adorno, Vermischte Schriften, II, Frankfurt a. M. 1986, str. 485; český překlad je můj vlastní.) Hlavním Adornovým záměrem je zde opět náboženskou mystiku a její pravdu sekularizovat. Jedná se o historickou pravdu, a Adorno Scholemovi vkládá do úst, že „,takovou historickou pravdu lze uchopit pouze v co největší vzdálenosti od jejího původu, totiž v završené sekularizaci“" (tamt.). Jakkoli lze z těchto útržků těžko usuzovat na to, že Adornova „kontemplace“ vděčí za svůj vznik pouze židovské mystice, pozitivní vztah k ní je vysledovatelný. Tento motiv by zasloužil bližší pozornost. 


\section{Struktura Adornovy minimální theologie: kontemplativní eschatologie}

Seel, jak jsem popsal výše, nazývá Adornovo dílo „filosofií kontemplace“. V tomto názvu je již obsažen jeho záměr s Adornovým dílem. Domnívá se totiž, že je třeba zcela opustit jeho utopický charakter, a nadále z Adornovy filosofie převzít její důraz na kontemplaci, nikoli ale činit kontemplaci eschatologií. K tomu Seela vede hlubší úvaha, v níž správně rozeznává základní paradox, který v Adornově filosofii nacházíme.

Adorno, jak Seel ukazuje, na jedné straně zdůrazňuje budoucnostní utopickou dimenzi, tj. vposled revoluci, na straně druhé pak kontemplaci. Mezi těmito dvěma principy ale vládne nepřekonatelný rozpor. Utopie, která nakonec spočívá v revoluci, vyžaduje radikální jednání, a to vposled jednání instrumentální. Vždyt' jak by bylo možno provést revoluci bez toho, aby se sáhlo k strategickému jednání, jednání, v němž vše další bude instrumentálně využito k dosažení daného cíle? Princip kontemplace ovšem instrumentální jednání neumožňuje; je totiž jeho přímým protikladem. Instrumentální jednání znamená využití věci nebo osoby k vlastním účelům. Kontemplace ale záleží v proražení instrumentální souvislosti, aby se otevřel prostor pro to, co věc chce jakoby sama od sebe. Kategorický imperativ „kontemplace“ může být podle Seela vyjádřen následovně: „Chovej se tak, abys s př́rodním i sociálním světem zacházel takovým zpo̊sobem, jako by to bylo svébytné jiné, nikoli pouze prostředek." 50 Jak ale zachovat tento imperativ, chceme-li uskutečnit revoluci? Revoluce za podmínek kontemplace je neuskutečnitelná.

Seel se v této souvislosti obává, že princip kontemplace neznemožňuje pouze revoluci, ale v zásadě znemožňuje jednání vůbec. Bez instrumentálního jednání není vposled možné ani si koupit rohlíky nebo nastoupit do tramvaje. To podle něho Adorno nedoceňuje, a dostává se tak do slepé uličky. Seel tvrdí: „Scestí, na němž se Adorno ocitá, nacházíme všude tam, kde Adorno pozvedá kontemplativní pozornost k všezahrnujícímu ideálu, místo aby důvěřoval její korektivní síle. "51 Adornova kritika je podle Seela nakonec bezzubá, protože jakmile postuluje zabsolutizovanou kontemplaci, je znemožněno jakékoli jednání. Adorno by tak nakonec propadl vlastnímu odsudku teorie bez praxe: „Introvertní architekt myšlenek bydlí za měsícem, který byl zkonfiskován extrovert-

\footnotetext{
50 M. Seel, Adornos Philosophie der Kontemplation, str. 60.

51 Tamt., str. 38.
} 
ními techniky."52 To, že na základě Adornovy kritiky se toho mnoho nemění, resp. že ideál revoluce je zde nedosažitelný, postřehli kromě Seela i další myslitelé. Už Sigfried Kracauer napsal, že nezná ,žádný jiný př́klad zdánlivě zasahující kritiky, která by měla tak málo síly“.53

Domnívám se, že Seel zde tematizuje centrální paradox Adornova díla: Jeho revoluce je neuskutečnitelná, jeho utopie nemůže být realizována, jeho kritika nebude nikdy v realitě tohoto světa zohledněna. Mezi utopií a kontemplací, správnou praxí a teorií, jednáním a respektem $\mathrm{k}$ věcem, ideálním budoucnem a snahou o nenásilí zeje nepřemostitelná propast.

To, že utopie je u Adorna neuskutečnitelná a čerpá z judeokřest’anských představ, z ní činí eschatologii. Eschatologii pro tyto účely rozumím jako nauce o posledních věcech, která je v tomto (dějinném) světě nerealizovatelná - „Boží království není z tohoto světa“. ${ }^{54}$ Na rozdíl od širšího pojmu utopie má prritom eschatologie zřetelné judeokřest'anské kořeny. A to Adornova utopie bezesporu má, jak ostatně naznačuje užití pojmů této tradice (vykoupení, zmrtvýchvstání těla, zákaz zobrazování). Adorno sám ostatně o své představě usmíření doslova říká: „Ve správném stavu by všechno bylo tak jako v židovském theologúmenon, jen maličko jiné, než to je, ale ani trochu si nelze představit, jaké by to potom bylo. “55

52 T. W. Adorno, Negative Dialektik, str. 13.

53 M. Seel, Adornos Philosophie der Kontemplation, str. 22.

54 Pojem eschatologie se v literatuře o Adornovi př́ležitostně použivá. Užívá ho např. P. R. Mendes-Flohr, To Brush History against the Grain: The Eschatology of the Frankfurt School and Ernst Bloch, in: Journal of the American Academy of Religion, 51, 1983, str. 631-650. O pojmu „eschatologie“ uvažují i autoři, kteří výslovně zdůrazňují Adornovu negativitu - např. podle Housemana je Adornova „mesianistická eschatologie“ desinterpretována, když je interpretována pozitivně. Jedná se prý o negativní eschatologii, v níž se nečerpá z př́slibu vykoupení, ale z tragédie Osvětimi, jež představuje negativní eschaton. T. Houseman, Auschwitz as Eschaton: Adorno's Negative Rewriting of the Messianic in Critical Theory, in: Millenium: Journal of International Studies, 42, 2013, str. 155-176.

55 T. W. Adorno, Negative Dialektik, str. 292. Usmíření by představovalo vyprázdnění od „,chtíče po objektu“; představovalo by stav, ve kterém subjekt vůči objektu už není nepřátelský. Taková představa zřejmě není daleko od Izajášova vidění: „Vlk bude přebývat $\mathrm{s}$ beránkem, pardál si lehne vedle kozlátka, tele a lvíče budou žrát pospolu a malé dítě je bude vodit. Kráva pást se bude s medvědicí, jejich mlád’ata spolu ulehnou, lev jako býk bude řezanku žvýkat. Kojenec si bude hrát nad dírou zmije a nemluvně sáhne rukou do skrýše jedovatého hada. Nikdo nebude škodit ani pustošit na celé mé svaté hoře, protože země se naplní poznáním Hospodina, jako vody pokrývají moře.“ (Iz 11,6-10) 
Základní strukturu Adornovy „minimální theologie“ lze proto popsat jako „kontemplativní eschatologii“, utopii s židovskokřest’anským pozadím, jejíž hlavní pozitivní náplní je představa realizované kontemplace ústící do smířené různosti.

\section{Centrální paradox Adornovy minimální theologie: kontemplace, nebo eschatologie?}

Jak si uvědomil už Seel, Adornova „kontemplativní eschatologie“ je paradoxní strukturou, protože není realizovatelná v tomto světě. Nekompromisní odsudek instrumentálního jednání, který nacházíme u Adorna, je proto u jeho následovníků většinou důsledně oslabován. Touto cestou se vydává i Seel. Ř́ká: „Kontemplace není exkluzivní chování, kterému je určeno, aby jednou nastoupilo místo dosavadní praxe. Všezahrnující norma potom zní, že individuální jednání stejně jako společenské instituce je třeba uvolnit co nejvíce a v co největší širri pro kontemplativní pozornost vůči jiným a jinému ... Vůbec už nemusí být hlásáno světu odcizené odvrácení od strategického a instrumentálního jednání, do centra sociální kritiky může nastoupit vnitřní kvalita způsobů chování.“"56

Seelovo odvrácení od Adornovy neuskutečnitelné revoluce a př́klon $\mathrm{k}$ reformismu představuje variantu mainstreamového prŕstupu k Adornově filosofii: Není-li revoluce uskutečnitelná, opust'me ji. Touto cestou se vydali myslitelé udávající směr pozdější kritické teorie, zejména Habermas, ${ }^{57}$ v Čechách pak např. Marek Hrubec. ${ }^{58}$ Existuje ale i druhá revoluční - cesta, kterou lze popsat takto: Není-li revoluce realizovatelná

56 Tamt., str. 39.

57 Habermas kritizuje Adorna za revoluční „,přetíženi'“ rozumu: „Hegelovi žáci nechtějí už dále rušit a uchovávat náboženství v myšlence..., nýbrž chtějí solidárním úsilím realizovat jeho profanizované obsahy ... Historický vývoj ovšem ukázal, že rozum je takovýmto projektem přetěžován.“ J. Habermas, Budoucnost lidské přirozenosti, str. 122. Není v možnostech rozumu snažit se uskutečnit ráj na Zemi, tvrdí Habermas; je-li revoluce pro rozum neuskutečnitelná, musíme myšlenku revoluce opustit.

58 Hrubec se snaží kritickou teorii jednak převést na globální úroveň, jednak ji uchopit pragmatičtěji než Adorno, tj. zrušit její negativitu - směřuje ke kritické teorii globální spravedlnosti, která by nastiňovala i pozitivní teorie změny. M. Hrubec a kol., Kritická teorie společnosti, Praha 2013. Aniž bych chtěl kritizovat Hrubcovo směřování, které rovněž považuji za důležité, vyslovuji se v tomto článku pro odlišné pojetí, které se vydává spíše náboženským než pragmatickým směrem, a Hrubcovo pojetí nepovažuji za adornovské. 
kvůli kontemplaci, oslabme kontemplaci natolik, aby revoluce uskutečnitelná byla. Tuto cestu reprezentuje např. Slavoj Žižek, ${ }^{59}$ v Čechách pak Michael Hauser. ${ }^{60}$

V tomto článku chci představit odlišnou cestu: Adornovský paradox neuskutečnitelné revoluce, ideál kontemplativní eschatologie není něčím, co bychom měli opouštět bud' směrem k reformismu, nebo k revoluční utopii. Neuskutečnitelnou revoluci je nejen možné, ale i prospěšné číst jako „náboženskou“ eschatologii. Z jakého důvodu?

Domnívám se, že Adorno zachytil ve svém díle paradox, který je hlubší a radikálnější, než jak se domnívali jeho nástupci. Ti ve svém díle oslabili bud' eschatologii (Habermas, Honneth, Seel), nebo kontemplaci (Žižek), popř. obojí. Jsou ale eschatologie nebo kontemplace vskutku tak zbytné principy, že je možné je navzájem usmírit oslabením jednoho $\mathrm{z}$ nich?

Pro oslabení Adornovy eschatologie, domnívám se, nehovoří ani tak argumenty jako spíše celkově sekulární charakter prací pozdějších generací Frankfurtské školy i ostatních myslitelů, kteří na Adorna navazují. V rámci sekulárního myšlení se eschatologie jeví jako nemožná myšlen-

59 Žižek kritizuje Adorna přesně z toho důvodu, že jeho dílo jakoby nikam nevede, nevede k revoluci, kterou předpokládá. Žižek se ptá: „と̌íká [Adorno]..., že boj probíhá věčně, nebo že na konci je utopická vize míru? Zde podle mého vidíme Adornovu nemohoucnost a je to také důvod tragiky toho, jak celá frankfurtská škola nikdy ani minimálně nemohla politicky operacionalizovat tento projekt ... Adorno, Horkheimer zůstali v naprosté abstrakci. Je velmi tragické, někde to cituji, že když byl Adorno ke konci svého života tázán: ,Dobře, kritizujete neustále buržoazní společnost, odcizení, totalitarismus, ale co máme dělat?‘, Adorno řekl otevřeně: „Nevím.' Bylo to úplně prázdné.“ S. Žižek - M. Hauser, Humanismus nestačí, Praha 2008, str. 21. Žižek věří tomu, že „kapitalismus má potenciálně př́iliš mnoho antagonismů, aby přežil, aspoň v tendenci““ (tamt., str. 23).

60 Hauser Adornovo odmítnutí praxe interpretuje jako důsledek dějinného intermezza, v němž praxe nedává smysl a které nastalo v Adornově době. Ř́íká v narážce na začátek Negativni dialektiky, že ,,jedinečný historický okamžik pro uskutečnění emancipace byl promeškán. Naplnění emancipačního myšlení se následkem toho odsouvá do vzdálené budoucnosti. Adorno však tuto perspektivu neopouští, nebot' to by znamenalo, že myšlení ztratilo svou svobodu a smířilo se s tím, že dějiny vládnou nad myšlením“. M. Hauser, Adorno: moderna a negativita, Praha 2005, str. 213. Ve svých dalších dílech pak Hauser, pokud ho interpretuji správně, doufá, že v současném kapitalismu uvidí rozpory, které by mohly naznačovat, že historický okamžik pro uskutečnění emancipace skutečně nastane. M. Hauser, Kapitalismus jako zombie, neboli, Proč žijeme ve světě př́zraků?, Praha 2012. Domnívám se, že i kdyby měl Hauser v hledání rozporů současného kapitalismu pravdu, neuskutečňuje se tu už adornovské „,vykoupení“, nýbrž jeho oslabená varianta. „Kontemplace“, kterou Adorno absolutizoval, nepřipouští řešení „,v tomto světě“. 
ková figura: Jestliže nám jde o revoluci v tomto světě, ale tato revoluce je ve skutečnosti neproveditelná, pak se jí vzdejme! Proč horovat pro něco, co beztoho nelze realizovat? Tento myšlenkový pochod vidíme nejen u Seela, ale i u Habermase nebo Honnetha. Je prý třeba stáhnout kritickou teorii ze snílkovských a kvazináboženských výšin do reálného světa.

Předpokladem těchto př́stupů je, že paradoxy je třeba opustit, že je třeba najít řešení a že to, co k němu nesměřuje, je špatnou cestou. Tento názor nepokládám za jediný možný, a už vůbec ne za jediný správný. Lze totiž ukázat, že myšlenková figura neuskutečnitelné revoluce, nedosažitelné utopie, tedy vposled eschatologie, je vskutku zásadní a že její opuštění není moudré.

Jedním z úhlů pohledu, které nás mohou dovést $\mathrm{k}$ tomuto závěru, je uvažování o eschatologickém charakteru revoluce z pohledu naděje. Produktivního charakteru Adornova aporetického př́stupu si všiml už Schiller, který vychází z Adornova výroku, podle něhož „bez naděje není žádného dobra“",61 a který tvrdí, že ,pouze ve vědomí aporie se zažehává jiskra naděje“. ${ }^{62}$ Schiller nicméně míní aporii chybějící transcendence, na kterou se Adorno přesto spoléhá. Domnívám se, že Adornův aporetický př́istup skutečně zažehává jiskru naděje, nikoli ovšem díky aporii chybějící transcendence, ale díky aporii neuskutečnitelné revoluce.

V úvahách Tomáše Halíka o naději (navazujících na Herberta Plüggeho, který naději zkoumal empiricky v př́padě smrtelně nemocných pacientů) najdeme rozlišení na dva typy naděje. První z nich se upíná k čemusi konkrétnímu:

„Naděje našeho každodenního života, našeho mluvení směřuje $\mathrm{k}$ tomu, aby to či ono nastalo, to či ono se pro nás pozitivně vyvíjelo, aby nám to či ono připadlo ... Je vždy vázána na objekt. A právě proto je v ní nutně cosi iluzorního: Vždyt' nikdy není úplně jisté, zda nastane to nebo ono. A právě proto k ní patř́ - právě tak jako iluze - vždy také zklamání. Nebot' směřuje vždy jen do světa..., jemuž je bytostně vlastní náhoda a kontingence." 63

V krizi tohoto typu naděje se však rodí nový typ naděje, který „,se neupírá k ničemu ve světě, k objektu patřícímu do světa, nýbrž její smysl

61 T. W. Adorno, Negative Dialektik, str. 270.

62 H. E. Schiller, Zergehende Transzendenz, str. 85.

63 H. Plügge, O naději, in: Bolest a naděje, Praha 1971, str. 248-249. Srv. T. Halík, Stromu zbývá naděje, Praha 2009, str. 95. 
je, že zabezpečuje budoucnost pacientovi, který cítí, že je ztracen...".64 Tomuto typu naděje ,nejde už o to, aby zmizela nemoc, bolest, slabosti a všechny symptomy, nýbrž o záchranu či ,znovuzachránění" osoby““ ${ }^{65}$

Druhý typ naděje, tedy naděje zrozená z krize, která sama sebe již neupíná k ničemu konkrétnímu, ale spíše se nejasným způsobem pozitivně zaměřuje k budoucnosti obecně, nazývá Halík „nadějí eschatologickou“, a staví se právě za tento typ naděje: „Když v mém vztahu k církvi převážila eschatologická naděje, opustila mne nervozita reformátorů, kteří svou nadějí míŕí jen ke krátkodobým a často pofidérním cílům..."66

Domnívám se, že Adornova naděje, jak se prezentuje ve figuře „vykoupení", jde obdobným směrem, jako to nastiňuje Halík. ${ }^{67}$ Skrze temnou krizi Osvětimi, v níž se zdá, že veškerá naděje pohasla, prochází Adorno procesem, $\mathrm{v}$ němž se $\mathrm{v}$ jeho díle utkává zklamaná naděje na dosažení lepšího světa s nejasným obrysem širší naděje, než je naděje na něco konkrétního a pojmově specifikovatelného - formuje se eschatologická naděje.

Obraz vykoupení, který Adorno využívá, je interpretovatelný jako záchytný bod eschatologické naděje; jeho nekonkrétnost a nejasnost je přitom nejen štítem před identifikujícím rozumem, ale i obranou před falešnou konkretizací naděje do nějakého konkrétního objektu.

Bylo by možná př́liš banální uchopit pojem „eschatologické naděje“ jako jakýsi ideální či jediný správný typ naděje, ke kterému se lze nějak jednoduše propracovat, jakmile jen trochu duševně (či duchovně) vyspějeme. Tvrzení, že čistá eschatologická naděje je čímsi žádoucím, by bylo bezesporu pádem do „zásvětnictví", a mohlo by opět být kritizováno Marxem jako „opium lidu“. Zdá se mi, že je třeba pojmout vztah klasické a eschatologické naděje spíše dialekticky: Naděje se upíná na objekty v tomto světě, je ale korigována širší eschatologickou nadějí, která ji překračuje a nedovolí fatální zklamání, které by vedlo k rezignaci. Naděje se pak může v určitém napětí pohybovat mezi konkrétními objekty ve světě a širší „neurčitou“ nadějí.

\footnotetext{
64 Tamt.

65 Tamt., str. 96.

66 Tamt., str. 105.

67 Ne ovšem směrem stejným. Halík, zdá se, přes svoji opatrnost poněkud tíhne k tomu upřednostnit naději eschatologickou před nadějí konkrétní. Adorno naproti tomu chová konkrétní naději na lepší svět, která v jeho díle, jak se mi zdá, figuruje vždy primárně, a teprve sekundárně je doplňována nadějí eschatologickou. U Adorna nacházíme tužší boj mezi nadějí konkrétní a nadějí eschatologickou, než je tomu u Halíka.
} 
Adornovo dílo, které je zásadně poznamenáno hrůzami 20. století, v souladu s tímto pojetím ukazuje spíše na těžký boj mezi zklamanou konkrétní nadějí a průhledem za ni směrem k eschatologické naději. Tento boj, zdá se mi, v Adornově díle nikdy nenachází jasné vyústění. Skrze paradox neuskutečnitelné revoluce, nerealizovatelného a nezobrazitelného vykoupení Adorno dosahuje možnosti současné orientace směrem k tomuto světu, aniž by v něm ale ulpěl natolik, že ho zklamání této naděje povede k rezignaci. Tvrdý boj mezi nadějí konkrétní a eschatologickou, mezi správnou praxí a její neuskutečnitelností, u Adorna umožňuje zastávat stanovisko, které není „zásvětnictvím“, zároveň se ale falešně neupíná ke konkrétnu.

Směr kritické teorie, který navrhují Seel, Habermas a další, ovšem považuje Adornovu eschatologii - a s ní de facto i eschatologickou naději - za přebytečnou. Zde dochází ke zploštění: Jsou skutečně ideály, jako je „,dorozumění“ nebo „korektivní síla kontemplace“, natolik nosnými a natolik dosažitelnými, aby se nemusely obávat, že se v príípadě selhání nadějí na jejich realizaci promění v čirou beznaděj? Zde, domnívám se, dospěl Adorno dále: Naléháním na nezobrazitelnost vykoupení vytvářel prostor pro eschatologickou naději, tedy vposled pro sílu nevzdávat se, jestliže jsou naše naděje zklamávány.

Autoři navazující na Adorna ovšem neoslabují pouze jeho „eschatologii“, nýbrž i jeho „kontemplaci“. Jak jsme viděli už u Seela, považuje Adornovu absolutizovanou kontemplaci za „světu odcizenou“ a vyslovuje se pro její korektivní roli. Je ale tento přístup vskutku nosný? Seel má bezesporu pravdu v tom, že princip kontemplace je svým způsobem „odcizený světu“, a přesvědčivě ukazuje, že instrumentální jednání, proti kterému Adorno vystupuje, je základním prvkem lidského života. Jeho závěr, že kontemplace má být pouze korektivní, je vskutku logický. Takový krok totiž za prvé opět umožní jednání, za druhé pak bude Adornovi práv v tom smyslu, že vystaví hráz vůči nekontrolované instrumentalizaci jednání.

Přesto se domnívám, že Adornova radikalita má své oprávnění a její oslabení je svým způsobem banalizací. Na jednom místě Negativní dialektiky Adorno píše: „Vinu života, který již jako čisté faktum olupuje jiný život o dech..., již nelze s životem smírit. Tato vina se reprodukuje neustále, protože nemůže být vědomí v žádném okamžiku plně přítomna. To a nic jiného nutí k filosofii.“68 V Minima Moralia pak jednání, které si takové viny není vědomo, jak již bylo připomenuto, přirovnává ke

68 T. W. Adorno, Negative Dialektik, str. 355. 
znásilnění ženy: „Čisté ,Tathandlung“ je prznění promítnuté na hvězdné nebe nad námi."69

Adorno možná vidí instrumentálnost hlouběji, než bychom se mohli domnívat: Nejedná se zřejmě pouze o znak osvícenské doby, nýbrž je spíše antropologickou konstantou. Život olupuje jiné životy o dech již jen tím, že je na světě: Při této větě nemusíme myslet pouze na zavražděné, které má Adorno na mysli v první řadě, ale i na mravence a brouky, které zašlapeme, jakmile vůbec začneme chodit, na bakterie, které náš organismus zabíjí zcela sám od sebe, na organismy, jimiž se naše těla živí, ale i na životní prostor, který si automaticky nárokujeme a který pak chybí dalším organismům - včetně ostatních lidí.

Instrumentálnosti se nelze zbavit. Do určité míry je náš organismus instrumentální sám od sebe, a to ještě dříve, než dojde k nějakému volnímu jednání. Zákaz instrumentálnosti, který je vlastní ideálu kontemplace, by tak musel znemožnit nejen veškeré volní jednání, ale lidský život jako takový. Přesto Adorno na kontemplaci trvá v takové radikalitě, že se stává hlavní náplní jeho eschatologie. Proč?

Adorno říká, že výlučně vina, kterou s sebou člověk nese už tím, že žije, nutí k filosofii. Filosofie je z tohoto úhlu pohledu pokus odčinit vinu, kterou člověk nese. Tato vina spočívá v instrumentálnosti, se kterou používá okolní svět. Nebylo by tedy ústupem od filosofie samé, kdybychom se pokoušeli boj proti instrumentálnosti oslabit?

Domnívám se, že princip kontemplace nemá u Adorna být chápán tak, že znemožňuje jednání a nakonec i život vůbec. Jeho funkce je jiná jako absolutní je Adornem postulován z toho důvodu, že život a jednání si musí být vědomo vlastní viny, kterou s sebou nese. Ryze sekulární uvažování, které pragmaticky uvažuje o vnějším světě a manipulaci s ním, uvažuje následujícím způsobem: Kontemplace je nemožná, oslabme ji tedy natolik, aby byla prakticky využitelná.

To by ale pro Adorna představovalo instrumentalizaci jeho filosofie. Adornovi nejde jen o praktické využití jeho principů ve společenských institucích, jeho filosofii je třeba chápat i jako hledání takového vnitřního morálního postoje, který by byl schopen dostát temným stránkám našeho života a tomu, abychom byli schopni proti těmto temným stránkám bojovat. A takovým postojem je u něho, jak se domnívám, postoj kontemplativní eschatologie. Eschatologie zde zajišt'uje naši schopnost jednat, aniž bychom propadli zoufalství ( $\mathrm{tj}$. je prostorem, v němž teprve může existovat naděje i ve své eschatologické podobě), kontemplace zajišt'u-

69 T. W. Adorno, Minima Moralia, str. 89. 
je, aby se naše jednání nepropadlo do pouhého znásilňování. Adornova kritická teorie je vposled kritikou nedostatku takového postoje u člověka současnosti z důvodu nadvlády společensky ustavených struktur instrumentální racionality.

Absolutizace kontemplace zajišt'uje, že se instrumentální povaha lidského jednání stává vědomou. To v zásadě znamená, že Adornovu kontemplaci je vskutku třeba chápat jako korektiv jednání, jak to činí Seel, avšak se současným udržením její absolutizace - jen ta totiž může dostát skutečnosti, kterou Adorno odhaluje, že totiž jednání s sebou nese vinu. Absolutizace kontemplace odpovídá poznání charakteru viny, které s sebou nese nevyhnutelnost instrumentálnosti v lidském životě. Člověk zabíjí už jen tím, že existuje; to nelze odmyslet snížením kontemplace na korektiv. Učinit z kontemplace pouhý korektiv znamená opustit poznání skutečnosti z pragmatických důvodů. Už nejde o to poznat instrumentální charakter lidského jednání, ale o jednání samo.

Jestliže se eschatologie u Adorna odhaluje jako nerealizovatelná, je tomu tak i proto, že nerealizovatelná je už její hlavní náplň - kontemplace. Nenásilný pohled na věc, o kterém Adorno hovoří, není dosažitelný jen proto, jak říká Seel, že znemožňuje jednání. Je vskutku obtížné si představit, jakým způsobem se zachovat nenásilně např. vůči králíkovi, který nám právě byl naservírován na talíri. Ale to není celý problém. Kontemplace je nemožná i proto, že ani naprostá absence jednání by stále neznamenala nenásilí. Je-li kontemplace nenásilným př́stupem k věci, nestačí pouze nejednat, nýbrž museli bychom se zříci vlastní existence. Nebýt násilný vůči onomu králíkovi by znamenalo ho nesníst, což je ještě představitelné, nebýt násilný vůči bakterii, která napadá náš organismus, by znamenalo zemřít.

Tvrdím tedy, že oba prvky Adornovy „theologie“, kontemplace i eschatologie, mají svůj dobrý smysl. Smysl eschatologie spočívá v jejím sebepřekračujícím charakteru, v ochraně před identifikujícím rozumem a $v$ podpoře takového typu naděje, který se ani neuchýlí k zásvětnictví a $\mathrm{k}$ útěku z tohoto světa, ani nebude propadat rezignaci, jakmile bude zklamán. Smysl kontemplace spočívá v neustálém vědomí závazku chovat se ke světu co možná nejméně násilně, přičemž vědomí nemožnosti naplnění ideálu nenásilí, tj. vědomí viny, je jedinou možnou zárukou, že nebudeme páchat zbytečné násilí, a současně vlastním pramenem toho, proč vůbec filosofujeme.

To odhaluje centrální paradox Adornovy filosofie - neuskutečnitelnou revoluci $-\mathrm{z}$ nového úhlu pohledu. Tento paradox se náhle nejeví jako cosi, co je třeba překonávat a čeho je třeba se zbavovat. Právě hrot neu- 
smířeného paradoxu - nenásilného jednání, které ale není uskutečnitelné; eschatologie, která není ani pojmenovatelná, natožpak realizovatelná; usmíření, které je nemožné; kontemplace, které nikdy nedosáhneme - je vlastní úrodnou půdou, ze které teprve má vyplývat lidské jednání. Lidské jednání se má „chvět“, aby neznásilnilo, a v tomto chvění se teprve proráží totalita instrumentální souvislosti, do níž je zachycen náš svět.

\section{Závěr}

V průběhu výše nastíněné interpretace Adornova díla jsem zajisté překročil jeho vlastní intence. Interpretovat jeho dílo jako vytvoření produktivního paradoxu neuskutečnitelné revoluce může být jen obtížně představeno tak, že se jednalo o Adornův vědomý záměr. Adorno revoluci současně chtěl a současně jí oponoval - byl uvnitř paradoxu, který nyní popisuji jakoby zvnějšku. Na tento charakter své interpretace jsem upozorňoval již v úvodu - nejde nakonec o to přeříkat přesně, co měl $\mathrm{v}$ úmyslu daný autor, ale objevit $\mathrm{v}$ tom, co přinesl, něco, co může oslovovat ještě dnes.

Popisovat ,zvnějšku“ - jako pozorovatel - paradox, v němž je někdo jiný uvězněný, může možná samo působit jako nepř́ípustná redukce nesmiřitelnosti, kterou se Adornova filosofie vyznačuje. Jako by již v prohlášení paradoxu za nutný spočívala jeho banalizace, jeho přijetí, jeho odsunutí jako čehosi vyřešeného. Domnívám se ovšem, že takto tomu je pouze zdánlivě: „Venku“ se člověk nachází pouze ve chvíli abstraktního myšlení, „venku“ je jen text. Ten je sám zpětnou reflexí života, života, který je sám zachycen v paradoxu, v němž se nacházel i Adorno.

Domnívám se, že Adornovi sekulární kritikové - z nichž jsem se $\mathrm{v}$ tomto článku konkrétněji věnoval pouze Martinu Seelovi - se nevědomky snaží jaksi ochočit a „normalizovat“ Adornovu divokou, paradoxní a těžko pochopitelnou filosofii. Tato obtížná uchopitelnost začíná zejména $\mathrm{v}$ těch oblastech, které úzce korelují s theologií a náboženstvím. Ze sekulárního úhlu pohledu se paradoxy typu neuskutečnitelné revoluce jeví jako cosi, co je třeba pragmatizovat, a paradox odstranit: Bud' se revoluce zřeknout, nebo se zřeknout toho, co brání v její realizaci. Z tohoto úhlu pohledu je v Adornově filosofii chyba.

Nemělo by asi smysl pokoušet se Adornovo dílo obhajovat jako celek. Nicméně pohled na náboženské prvky v jeho díle a snaha je pochopit i nábožensky - tj. nikoli pouze jako nějakou pragmatizovatelnou součást vnější reality, kterou je třeba přivést v ideální podobě za každou cenu 
$\mathrm{k}$ životu v tomto světě - může být inspirativní. Z tohoto úhlu pohledu se jedná o částečnou sekularizaci, která využívá dialektiky mezi „tímto světem“ a „vykoupením“, a snaží se zůstávat v tomto světě (aby byla schopna sledovat $v$ tomto světě určitou praxi), aniž by $v$ něm ovšem zcela ulpěla (a byla tak vystavena jistotě rezignace, která následuje po selhání praxe). To je možný smysl Adornova pojmu „vykoupení“.

Jsem toho názoru, že Adornovo dílo je popsatelné slovy Henta de Vriese jako „minimální theologie“ v tom smyslu, že nezobrazitelné vykoupení, z něhož čerpá, minimalizuje pozitivní theologické obsahy. Ty ovšem v Adornově díle zřejmě př́tomny jsou: Vykoupení je zřejmě interpretovatelné jako „neidentické“ rozumu a je minimálním theologickým obsahem Adornova díla. To lze podložit např. tím, že Adorno za podmínku své filosofie považuje to, že smrt není absolutní. Musí tedy existovat cosi mimo materialistickou filosofii, co takovou ,porážku smrti“ zajistí, jinak, jak říká Adorno, ,je vše ničím“. Tato podmínka se ovšem současně nachází mimo možnosti Adornova chápání rozumu.

De Vries a ostatní analytici, kteří analyzují Adornovo dílo jako „minimální theologii“, jednostranně zdůrazňují budoucnostní eschatologický charakter Adornovy filosofie a podceňují význam př́itomnostního principu kontemplace, který naplno odhaluje až Seel. Z pohledu analytiků náboženského prvku u Adorna se jeho dílo jeví většinou jako negativní kritika současnosti - a to bud' zcela, nebo s minimální stopou pozitivního prvku. Tím zůstávají tito analytici ve stínu sebeprezentace Adorna, který tvrdohlavě trval na tom, že jeho dialektika je negativní. Tak tomu ovšem, jak ukazuje Seel, není: Adornova eschatologie obsahuje výrazný pozitivní prvek kontemplace, který je jeho hlavní náplní. Kontemplace spočívá v dlouhém nenásilném pohledu na poznávanou věc, v němž už věc neznásilňujeme, ale necháváme ji žít podle její intence. Kontemplace je u Adorna principem, který staví zásadní hráz vůči násilí, a její absolutizace, kterou Adornovi analytici kritizují, zachycuje reálnou aporii, v níž je uvězněno lidské jednání. To totiž nikdy nemůže být skutečně nenásilné.

Adornovo dílo je popsatelné jako „kontemplativní eschatologie“. Adorno před nás staví aporetickou strukturu, s níž si jeho pozdější interpreti př́liš nevěděli rady a snažili se ji odstranit. Ukazuje se ale, že tato struktura má hluboký smysl: Udržuje nás v tomto světě, aniž bychom v něm falešně ulpěli, a udržuje vyhrocené vědomí paradoxu nemožnosti nenásilného jednání, které jedině může zabránit tomu, abychom sklouzávali k jednání, které už nebude než „przněním“. Jeden ze zajímavých, i když dosud okrajových způsobů četby Adornova díla tak spočívá v identifikaci základní „theologické“ struktury, která je tvořena „kon- 
templativní eschatologií“. Ta může - jak se domnívám - být inspirativní jak z hlediska promýšlení možností „minimálních theologií“ dnes, tak z hlediska kritické sociální teorie, která by mohla začít těžit i ze svých theologických kořenů. ${ }^{70}$

\section{ZUSAMMENFASSUNG}

In der vorliegenden Analyse von Adornos Werk wird die Interpretation, laut der Adornos Philosophie als eine Form von „Theologie“ gelesen werden kann, untersucht und weitergeführt. Laut Hent de Vries solle Adornos Werk als eine „minimale Theologie“ mit eschatologischen Konnotationen verstanden werden. Diese These wird mit der Interpretation Martin Seels, der die negative Natur von Adornos Werks ablehnt und von einer positiven „Philosophie der Kontemplation“" spricht, in Zusammenhang gebracht. Adornos kritische Theorie wird dann als eine „kontemplative Eschatologie" dargelegt und im Hinblick auf das Paradox der Unvereinbarkeit der Kontemplation, die vom Handeln abzuraten tendiert, und der Eschatologie, die zum revolutionären Handeln aufruft, weiter analysiert. Es wird die Behauptung vertreten, dieses Paradox könne produktiv verwertet werden.

The article undertakes an analysis of the "religious" element in Theodor W. Adorno's philosophy, taking up the thesis that it should be read as a specific form of "theology". Following Hent de Vries, I argue that it may be adequate to interpret Adorno's critical theory as a "minimal theology" with eschatological connotations; however, considering Martin Seel's argument about "contemplation" as a positive core of Adorno's negative dialectics, I cast aside the widespread assumption that Adorno's philosophy is largely negative and interpret it as a "contemplative eschatology". In so doing, I investigate the paradox of contemplation, which disables us from action, and eschatology, which seems to demand radical revolutionary action, maintaining that the paradox does not represent the blind spot of Adorno's philosophy, but one of its strong points.

70 Tento text vznikl na Fakultě sociálních věd Univerzity Karlovy za podpory projektu GA UK č. 1592514 (50 \%) a SVV260339 (50 \%). 